\title{
Early-onset cerebellar ataxia with retained tendon reflexes
}

INSERM

\section{Source}

INSERM. (1999). Orphanet: an online rare disease and orphan drug data base. Early-onset cerebellar ataxia with retained tendon reflexes. ORPHA:1177

Early onset cerebellar ataxia with retained reflexes (EOCARR) or Harding ataxia is a cerebellar ataxia characterized by the progressive association of a cerebellar and pyramidal syndrome with progressive cerebellar ataxia, brisk tendon reflexes, and sometimes profound sensory loss. 